\title{
Differential Thermal Analysis of St. Augustinegrass
}

\author{
H.W. Philley, C.E. Watson, Jr., J.V. Krans, J.M. Goatley, Jr., and \\ F.B. Matta \\ Department of Plantand Soil Sciences, Mississippi State University, Mississippi \\ State, MS 39762
}

Additional index words. Stenotaphrum secundatum, DTA, freezing tolerance, winter survival

\begin{abstract}
The objective of this study was to relate the lethal freezing temperatures of St. Augustinegrass [Stenotaphrum secundatum (Walt.) Kuntze] genotypes, as measured by differential thermal analysis (DTA), to winter survival observed in the field. DTApredicted lethal temperatures of $14 \mathrm{St}$. Augustinegrass genotypes ranged from $\mathbf{- 7 . 7}$ to -4.7C. Regression of field winter survival vs. DTA-predicted lethal temperatures resulted in an $r^{2}=0.57$ for one field trial that evaluated cultivars with a relatively narrow range of expected freezing tolerance. In a second study evaluating cultivars with a greater range of freezing tolerance, $r^{2}$ was 0.92 when winter survival was regressed on DTA-predicted lethal temperatures. DTA was successful in measuring freezing avoidance of St. Augustinegrass cultivars.
\end{abstract}

St. Augustinegrass is a popular perennial turfgrass in the southern and Gulf Coast regions of the United States. The geographical distribution of St. Augustinegrass in the United States is limited by lack of freezing tolerance. Differential thermal analysis (DTA) is a useful technique to rapidly measure cold hardiness in several horticultural and woody plants (Ashworth, 1982; George et al., 1974; Ketchie and Kammereck, 1987). To our knowledge, DTA has not been used previously to predict lethal temperatures in turfgrasses.

When DTA is used to study freezing of water in some flower buds, two distinct freezing events occur (Ashworth, 1982; Flinn and Ashworth, 1994; Quamme, 1991; Warmund et al., 1988). An initial high-temperature exotherm (HTE) between 0 and $-10 \mathrm{C}$ is associated with ice formation in bud scales and axis tissue. This is usually a relatively pronounced exotherm and may involve freezing of extracellular and intracellular water. Less distinct, low-temperature exotherms (LTE) occur at temperatures lower than $-10 \mathrm{C}$ and result from freezing of water in the developing floral organs. This type of intracellular freezing is usually lethal. Ashworth (1982) reported that the extent of such supercooling in peach [Prunus persica (L.) Batsch] buds was influenced by cooling rate. Buds cooled at $2 \mathrm{C} /$ $\mathrm{h}$ exhibited both HTEs and LTEs. When buds were cooled at $20 \mathrm{C} / \mathrm{h}$, only HTEs occurred and were single or two-fused peaks. Quamme (1991) stated that transitory supercooling may be a protective mechanism in tender plants. Deep supercooling has not been detected in herbaceous plants. Freezing avoidance by su-

Received for publication 9 Feb. 1995. Approved for publication 25 July 1995. Contribution of the Mississippi Agricultural and Forestry Experiment Station Journal article no. J-8659. This research was funded by project no. MIS-1325. The cost of publishing this paper was defrayed in part by the payment of page charges. Under postal regulations, this paper therefore must be hereby marked advertisement solely to indicate this fact. percooling is of unknown significance in turfgrasses (DiPaola and Beard, 1992).

The objective of this study was to evaluate DTA as a technique for measuring St. Augustinegrass freezing tolerance by comparing DTA-predicted lethal temperatures to field survival ratings.

\section{Materials and Methods}

St. Augustinegrass genotypes evaluated in this study were included in one or both of two field trials located at the Mississippi State Univ. Plant Science Research Center. The Mississippi location of the National St. Augustinegrass Test-1989 was established 14 June 1990 and included commercially available and improved experimental cultivars. Plots were arranged in a randomized complete-block design with three replications. Six 76-mmdiameter vegetative plugs were planted within each $2.75 \times 2.75-\mathrm{m}$ plot.

A St. Augustinegrass germplasm evaluation trial was planted adjacent to the National St. Augustinegrass Test in July 1990. Entries in this trial included commercially available cultivars, ecotypes, and plant introductions. The design was a randomized complete block with four replications. Plots measured $1.0 \times$ $1.0 \mathrm{~m}$. A 100 -mm-diameter $\times 120$-mm-deep plug was planted in the center of each plot.

Soil type for both field trials was a Marietta fine sandy loam (fine-loamy, siliceous, Fluvaquentic Eutrochrept), pH 6.8. Soil tests revealed $\mathrm{P}$ and $\mathrm{K}$ at 307 and $290 \mathrm{~kg} \cdot \mathrm{ha}^{-1}$, respectively. Nitrogen was applied May to August in four equal applications for a total of $19.6 \mathrm{~g} \cdot \mathrm{m}^{-2}$ per year. Phosphorus and $\mathrm{K}$ were applied at 2.1 and $4.1 \mathrm{~g} \cdot \mathrm{m}^{-2}$ each spring from a $13 \mathrm{~N}-13 \mathrm{P}-13 \mathrm{~K}$ fertilizer. Both field trials were mowed weekly to a $64-\mathrm{mm}$ height throughout the growing season.

Winter survival of these field trials was evaluated in Apr. 1991-93. Survival was assessed by assigning a score of 1 to 9 to each plot, where $1=$ complete winterkill and $9=$ complete survival. Simultaneous ratings by three researchers were averaged to arrive at a survival score for each plot within each year.

A preliminary DTA experiment was conducted to evaluate exotherms that result when St. Augustinegrass is frozen. Nodes of ' $\mathrm{Ra}$ leigh' were frozen at cooling rates of 2 and 20C/h (Fig. 1). Only HTEs were present regardless of cooling rate. Freezing of differing tissues within nodes could not be detected as separate events. Nodes cooled at $2 \mathrm{C} / \mathrm{h}$ exhibited an $\mathrm{HTE} \approx 1^{\circ}$ higher than those cooled at $20 \mathrm{C} / \mathrm{h}$.

After field observation in 1991, 14 St. Augustinegrass genotypes that displayed a wide range of freezing tolerance were chosen for DTA, including 'DelMar', 'Floratam', FX33, 'Mercedes', MSA-10, MSA-11, PI365031, PI 410356, PI410358, 'Raleigh', SATX 8262, 'Seville', 'Texas Common', and TR6-3 (DD-I). Two single-node samples were randomly chosen from each genotype and subjected to DTA on each of seven dates during Nov. and Dec. 1991. Nodes were cut into 15$\mathrm{mm}$ segments, each containing the bases of two leaf sheaths, two axillary buds, nodal tissue, and a portion of the preceding internode. Each node was attached to a thermocouple by wrapping a $35 \times 35$-mm square of aluminum foil around the stem. An additional thermocouple was held in close proximity to the sample to measure the surrounding air temperature (i.e., reference temperature). Samples and attached thermocouples were enclosed in a Styrofoam insulated box to stabilize the temperature. The insulated box was placed inside a chest freezer maintained at $-20 \mathrm{C}$. The chilling rate of the samples was $\approx 20 \mathrm{C} / \mathrm{h}$. Thermocouples were connected to a CR7 data logger (Campbell Scientific, Logan, Utah) that monitored 28 channels at 15 -sec intervals. As reference temperatures dropped, the difference between the sample temperature and the reference temperature (i.e., differential temperature) was recorded. Data were stored on a cassette tape and downloaded to a microcomputer for processing. An increase in the differential temperature indicated an exotherm. The reference temperature at the onset of an exotherm was recorded as the lethal temperature for each node. Data were tested by analysis of variance as a randomized complete-block design with the seven dates of freezing used as blocks; this allowed 14 observations for each genotype. A simple linear regression was used to test the relationship between DTA-predicted lethal temperatures vs. field trial survival scores. Because there was a significant genotype $\times$ year interaction for field survival, the 1992 ratings were used alone for comparison to DTA. Survival ratings recorded in Spring 1992 likely best reflect the DTA measurements made the preceding fall.

\section{Results and Discussion}

Winter survival among genotypes differed significantly each year in both field trials. Regression of DTA-predicted lethal temperatures vs. field survival ratings resulted in an $r^{2}=0.57$ for the National St. Augustinegrass 


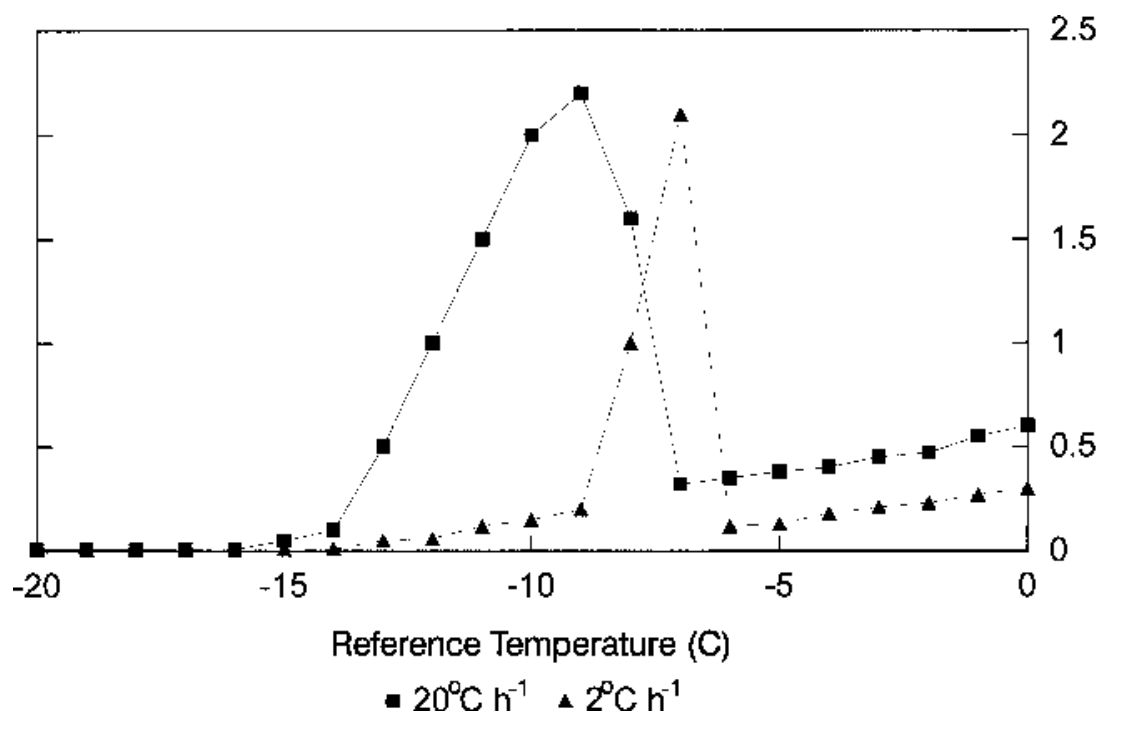

Fig. 1. Typical exotherms detected by DTA when freezing excised nodes of 'Raleigh' St. Augustinegrass at two cooling rates.

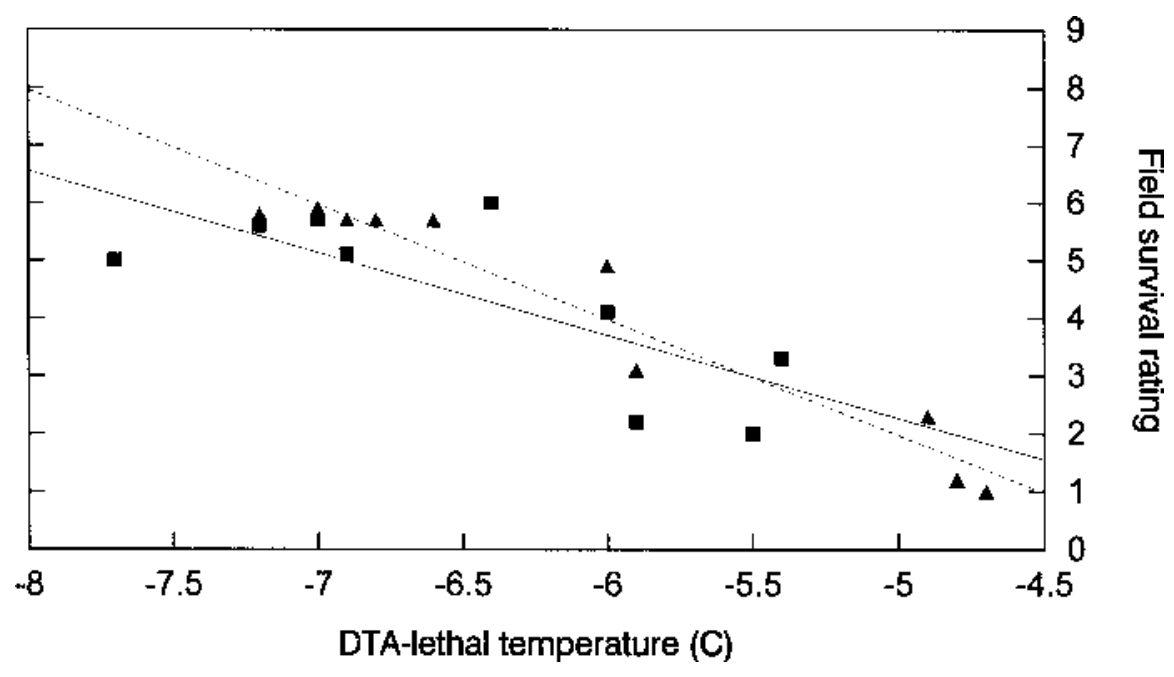

Fig. 2. Regression of field survival ratings vs. DTA-predicted lethal temperatures of St. Augustinegrass genotypes; ( $\mathbf{\square})$ National St. Augustinegrass Test, y $=-4.7-1.4 \mathrm{x}\left(r^{2}=0.57, P=0.019\right) ;(\boldsymbol{\Delta})$ germplasm trial, $\mathrm{y}=-8.0-2.0 \mathrm{x}\left(r^{2}=0.92, P=0.0001\right)$.

Test and an $r^{2}=0.92$ for the germplasm evaluation trial (Fig. 2). The higher $r^{2}$ for field survival vs. DTA-predicted lethal temperatures for the germplasm evaluation trial was expected, since this trial included more diverse entries, ranging from locally adapted ecotypes to nonadapted plant introductions that required replanting each year. Conversely, genotypes included in the National St. Augustinegrass Test were improved commercial and experimental cultivars that did not exhibit a wide range of freezing tolerance as in the germplasm trial.

Lethal temperatures predicted by DTA ranged from -4.7 to $-7.7 \mathrm{C}$, and there were differences among genotypes. Genotypes exhibiting DTA-predicted lethal temperatures lower than the mean (-6.2C) were 'Mercedes',
MSA-10, MSA-11, 'Raleigh', 'Texas Common', SATX 8262, and 'DelMar'. Genotypes with lethal temperatures higher the mean were 'Seville', 'Floratam', FX-33, TR 6-3 (DD-I), PI 410358, PI 410356, and PI 365031.

While field evaluation determined winter survival, DTA was effective in detecting differences in freeze avoidance of excised nodes among St. Augustinegrass genotypes. The relationship between the results of the two methods suggests that freeze avoidance may play a role in the winter survival of St. Augustinegrass. Beard et al. (1980) stated that other potential causes of winter injury can occur in combination with low-temperature kill. Since both techniques used field-conditioned plants, field evaluation required less labor and specialized equipment. DTA provided a quantitative esti- mate of lethal low temperature for each genotype; field evaluation required subjective visual ratings. Further refinement of the DTA technique may allow for faster selection cycles than are currently possible due to seasonal limitation in the field. In a mild winter, temperatures may not be low enough to cause differences in field survival. In a severe winter, entire experiments can be killed before any data can be obtained. Using greenhouse-reared plants, DTA would ensure at least one selection cycle each year. Evaluation of management practices that enhance cold tolerance of turfgrasses also may be a possible application for DTA.

At the fast rate of cooling used, all of the water within nodes appeared to freeze in one event. In every case, only large HTEs were observed. Intact stolons may behave differently from the excised nodes used in this experiment. We made no attempt to define factors other than genetics that affect freezing avoidance of St. Augustinegrass as measured by DTA. Studying the relationships of other factors to DTA-determined lethal temperatures may lead to direct measurement of characteristics that affect freezing avoidance in St. Augustinegrass.

\section{Literature Cited}

Ashworth, E.N. 1982. Properties of peach flower buds which facilitate supercooling. Plant Physiol. 70:1475-1479.

Beard, J.B, J.M. DiPaola, and S.M. Batten. 1980 Development of a cold stress simulator to be used in screening for cold hardiness, p. 36-40. In: Texas turfgrass research-1978-79. Texas Agr. Expt. Sta. Prog. Rpt. 3675.

Burke, M.J., L.V. Gusta, H.A. Quamme, C.J. Weiser, and P.H. Li. 1976. Freezing and injury in plants. Annu. Rev. Plant Physiol. 27:507-528.

Callan, N.W., J.M. Story, and R.R. Roche. 1986. Thermoelectric modules and a computerized data acquisition system to determine insect supercooling points. Ann. Entomol. Soc. Amer. 79:60-61.

DiPaola, J.M. and J.B. Beard. 1992. Physiological effects of temperature stress, p. 231-267. In: D.V. Waddington, R.N. Carrow, and R.C. Shearman (eds.). Turfgrass. Agron. Monogr. 32. Amer. Soc. Agron., Madison, Wis.

Flinn, C.L. and E.N. Ashworth. 1994. Blueberry flower-bud hardiness is not estimated by differential thermal analysis. J. Amer. Soc. Hort. Sci. 119:295-298.

George, M.F., M.J. Burke, and C.J. Weiser. 1974. Supercooling in overwintering azalea flower buds. Plant Physiol. 54:29-35.

Ketchie, D.O. and R. Kammereck. 1987. Seasonal variation of cold resistance in Malus woody tissue as determined by differential thermal analysis and viability tests. Can. J. Bot. 65:26402645.

Quamme, H.A. 1991. Application of thermal analysis to breeding fruit crops for increased cold hardiness. HortScience 26:513-517.

Warmund, M.R., M.F. George, and B.G. Cumbie. 1988. Supercooling in 'Darrow' blackberry buds. J. Amer. Soc. Hort. Sci. 113:418-422. 